\title{
Pacific Northwest Laboratory Monthly Report on Strontium Heat Source Development Program, Nuclear Research and Applications Division for October 1976
}

H. T. Fullam

November 1976

Prepared for the Energy Research and Development Administration under Contract E(45-1)-1830 


\section{NOTICE}

This report was prepared as an account of work sponsored by the United States Government. Neither the United States nor the Energy Research and Development Administration, nor any of their emplovees, nor any of theit contractors, subcontraciors, of their emplovees. makes any warranty, express or implied, of assumes any legal liability or responsibility far the accutacy, completeness or usefuiness of any intormation. apparatus. product or process disclosed, or represents that its use would not infringe privately owned rights.

PACIFIC NORTHWEST LABORATORY

operated by

BATTELLE

for the

ENERGY RESEARCH AND DEVELOPMENT ADMINISTRATION

Under Contract E)-76-C-0b-1830

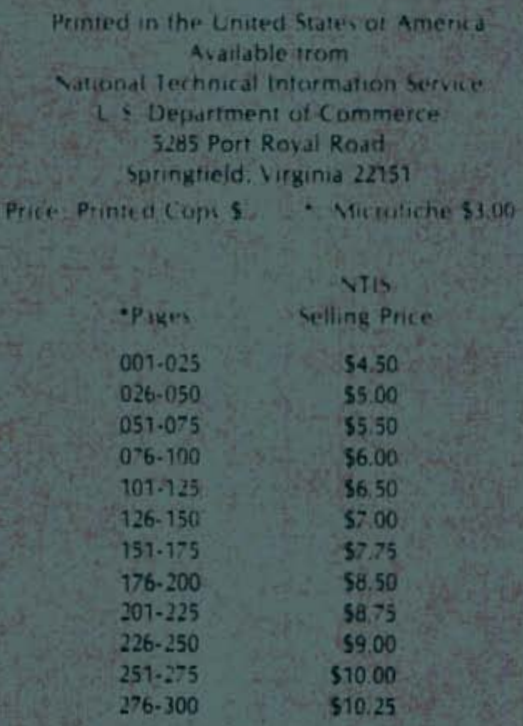


BNWL $-1845-29$

UC -23

PACIFIC NORTHWEST LABORATORY

STRONTIUM HEAT SOURCE DEVELOPMENT

PROGRAM, NUCLEAR RESEARCH AIVD

APPLICATIONS DIVISION FOR OCTOBER 1976

H. T. Fullam

January 1976

BATTELLE

Pacific Northwest Laboratories

Richland, Washington $9935 ?$ 


\section{CONTENTS}

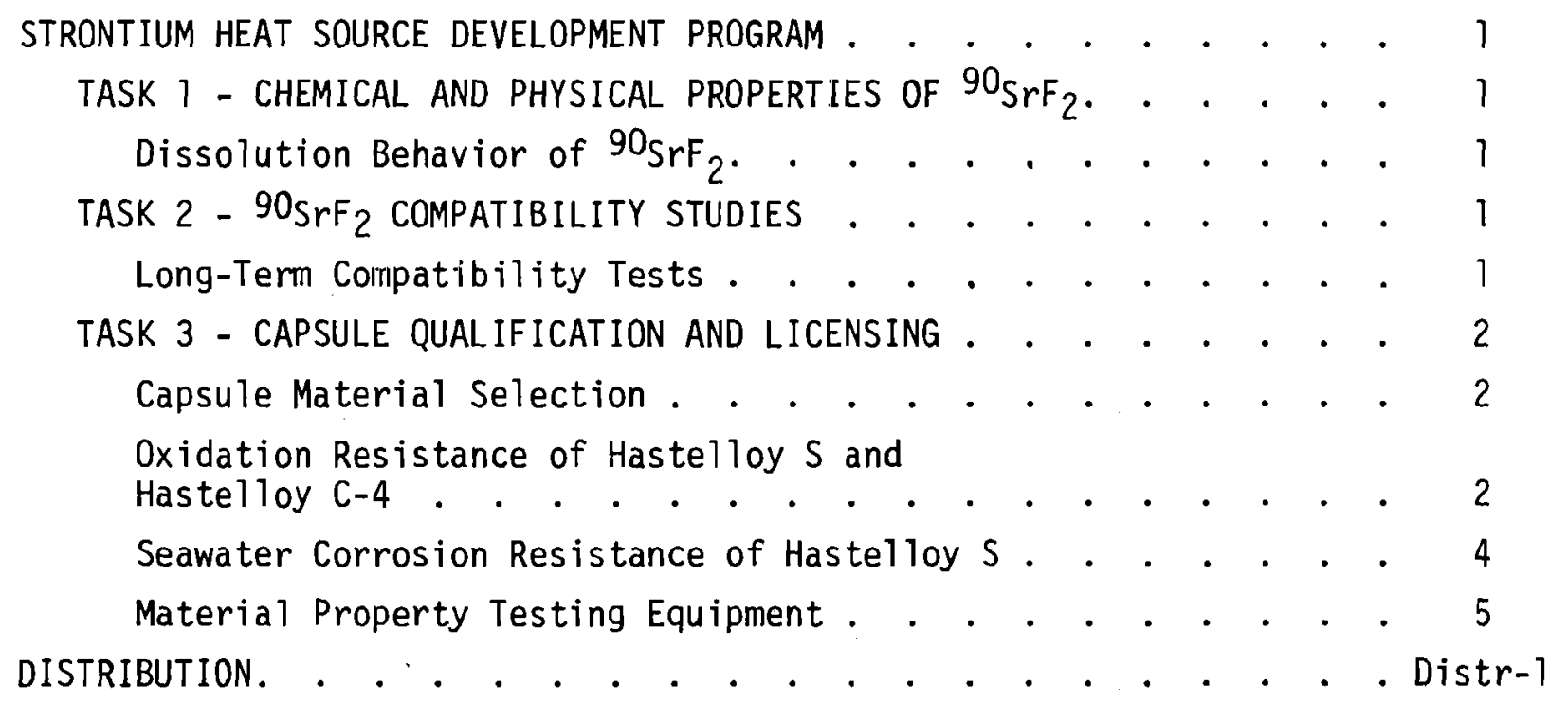




\section{STRONTIUM HEAT SOURCE DEVELOPMENT PROGRAM}

J. H. Jarrett, Program Manager

H. T. Fullam, Principal Investigator

D. G. Atteridge

At Hanford, strontium is separated from the high-level waste, converted to the fluoride, and doubly encapsulated in small, highintegrity containers for subsequent long-term storage. The fluoride conversion, encapsulation and storage take place in the waste Encapsulation and Storage Facilities (WESF). The encapsulated strontium fluoride represents an economical source of $90_{\mathrm{Sr}}$ if the WESF capsule can be licensed for heat source applications under anticipated use conditions. The objectives of this progrom are to obtain the data needed to license $90 \mathrm{SrF}_{2}$ heat sources and specifically the WESF $90 \mathrm{SrF}_{2}$ capsules. The information needed for licensing can be divided into three general task areas:

Task 1 - Chemical and Physical Properties of $90 \mathrm{SrF}_{2}$

Task 2 - $9 \mathrm{SrF}_{2}$ Compatibility Studies

Task 3 - Capsule Qualification and Licensing

Efforts are proceeding concurrently on all three tasks to obtain the required information.

TASK 1 - CHEMICAL AND PHYSICAL PROPERTIES OF ${ }^{90}{ }^{\mathrm{SrF}} 2$

Dissolution Behavior of ${ }^{90} \mathrm{SrF}_{2}$

The first draft of the topical report on the dissolution behavior of ${ }^{90} \mathrm{SrF}_{2}$ has been reviewed by NRA. The revised final draft of the report is now being typed and will be ready for printing in November.

TASK $2-{ }^{90}$ SrF $_{2}$ COMPATIBILITY STUDIES

\section{Long-Term Compatibility Tests}

All of the compatibility tests are continuing on schedule. Metallographic examination and electron microprobe analysis of the $6000 \mathrm{hr}$ tests with nonradioactive $\mathrm{SrF}_{2}$ is continuing and should be completed in November. 
The 6-month test with the full-size WESF capsule filed with fuelgrade ${ }^{90} \mathrm{SrF}_{2}$ has been completed. Arrangements have been made with ARHCO to section the capsule. Test specimens will be taken from several locations along the length of the inner Hastelloy C-276 capsule and analyzed to determine the extent of metal-fluoride interaction.

\section{TASK 3 - CAPSULE QUALIFICATION AND LICENSING}

D. G. Atteridge of the Metallurgy Research Section has been assigned to the Strontium Heat Source Development Program. He will assume responsibility for Task 3 of the program.

\section{Capsule Material Selection}

The oxidation assistance and seawater corrosion resistance of Hastelloy $\mathrm{C}-4$ and Hastelloy $\mathrm{S}$ are being determined using both solution heat-treated and thermally-aged test specimens.

Oxidation Resistance of Hastelloy S and Hastelloy C-4

The oxidation resistance of solution heat-treated Hastelloy $S$ was determined at temperatures of $600,700,800,900,1000$ and $1100^{\circ} \mathrm{C}$. The test specimen was cut from a $0.063-i n$. sheet and was 2.00 in. $x 1.00$ in. The specimens were degreased prior to testing but the mill scale was not removed. The cleaned specimens were weighed and then placed in preheated air atmosphere muffle furnaces. Periodically, the specimens were removed from the furnaces, cooled to room temperature, weighed, and then returned to the furnaces. The tests lasted for $1000 \mathrm{hr}$. At $1000^{\circ} \mathrm{C}$ or 1 ess the specimens formed an adherent oxide scale and specimen weights increased continuously with time at temperature (see Figure 1). The formation of the adherent oxide scale followed a parabolic time dependence. At $1100^{\circ} \mathrm{C}$ an adherent oxide scale formed initially; but spalling of the oxide scale began after about $50 \mathrm{hr}$ exposure with a corresponding loss of weight (see Figure 2). Only slight spalling was observed up to $550 \mathrm{hr}$ exposure, but then the samples began to lose weight very rapidly. 


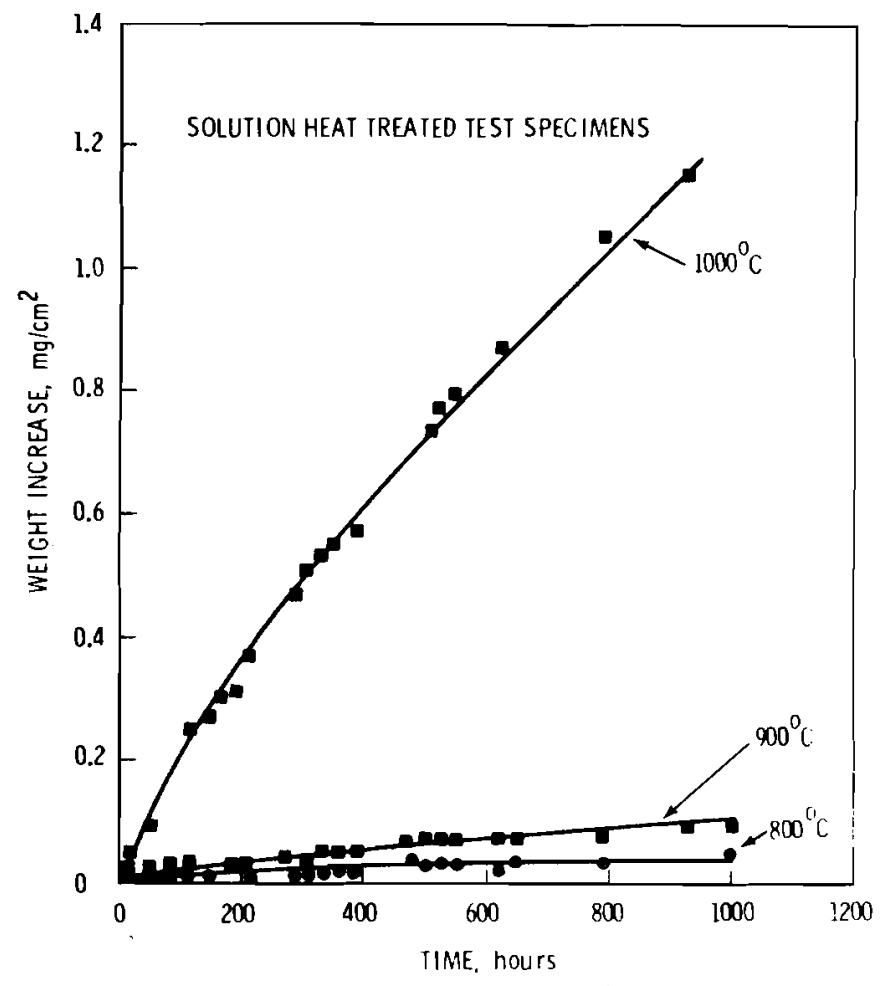

FIGURE 1. Oxidation of Hastelloy S

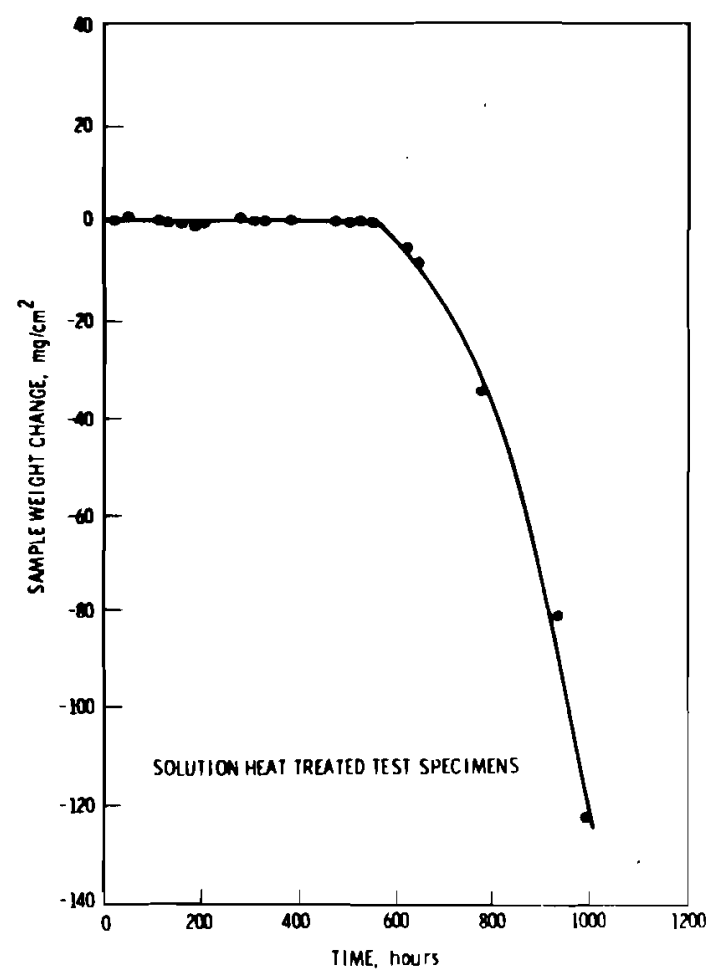

FIGURE 2. Oxidation of Hastelloy S at $1100^{\circ} \mathrm{C}$ 
Comparison of the oxidation data for Hastelloy $S$ with the data previously reported for Hastelloy C -4 (BNWL-1845-28) shows that the Hastelloy $S$ oxidizes at a much slower rate than the Hastelloy $\mathrm{C}-4$. However, both alloys suffer the problem of oxide spalling at the higher temperatures.

It was reported earlier (BNWL-1845-28) that when solution heat-treated Hastelloy $\mathrm{C}-4$ was heated in air at $1000^{\circ} \mathrm{C}$ and higher for extended periods of time the specimens lost weight because of the spalling of the oxide layer. At $1100^{\circ} \mathrm{C}$ the weight loss of the Hastelloy $\mathrm{C}-4$ exhibited a linear time dependence (see Figure 3 ). It was felt that the spalling of the oxide layer may have been due to the thermal stresses produced when the test specimens were removed periodically from the furnace, cooled to room temperature, weighed, and then returned to the furnace for additional exposure. Therefore, a second series of tests was carried out in which several solution heattreated Hastelloy C-4 specimens were held at $1100^{\circ} \mathrm{C}$ for different times and then removed from the furnace and weighed. This eliminated the thermal cycling the specimens in the first series of tests were subjected too. The results of the second series of tests showed that spalling of the oxide layer occurred at $1100^{\circ} \mathrm{C}$ even when the specimens were not thermally cycled (see Figure 3 ). Without thermal cycling a much larger exposure time was required before spalling began; but once spalling began the weight loss exhibited a linear time dependence.

Seawater Corrosion Resistance of Hastelloy $S$

Laboratory tests were carried out to measure the corrosion resistance of solution heat treated Hastelloy $S$ to natural seawater. The test specimens were cut from the same sheet as the specimens used for the oxidation tests. Specimens dimensions were $2.00 \times 1.00 \times 0.063 \mathrm{in}$. Some specimens were in the "as received" condition with mill scale on the major surfaces. Other specimens were polished to remove the scale prior to testing. TIG welded specimens were also evaluated. The tests were carried out at $23^{\circ} \mathrm{C} \pm .1^{\circ} \mathrm{C}$ with and without aeration. The tests lasted $1000 \mathrm{hr}$, and the 


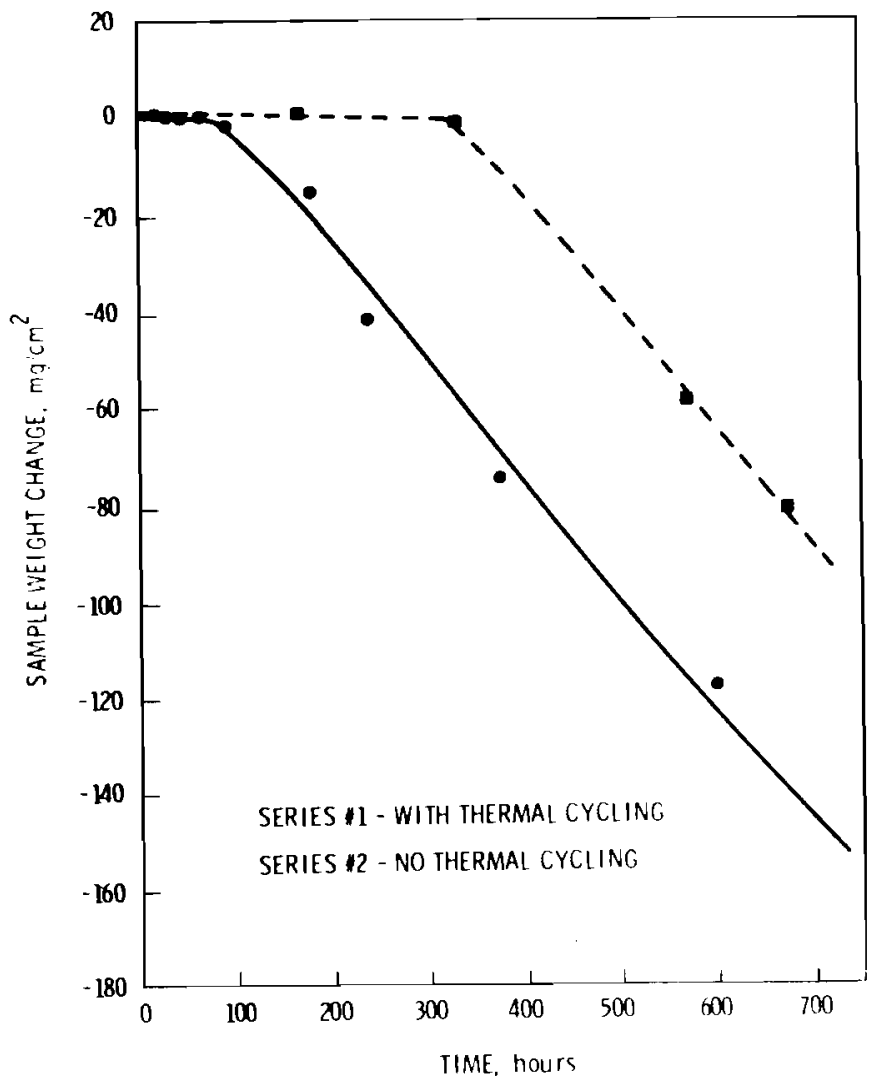

FIGURE 3. Oxidation of Hastelloy $\mathrm{C}-4$ at $1100^{\circ} \mathrm{C}$

Hastelloy $S$ was found to be very resistant to attack by the seawater. Microscopic examination of the specimens showed no evidence of attack; and the maximum weight loss observed with any specimen was less than $1 \mathrm{mg}$, which corresponds to a weight loss of $<0.04 \mathrm{mg} / \mathrm{cm}^{2}$.

\section{Material Property Testing Equipment}

An instrumented Tinis 01 sen Universal Impact Testor having a capacity of $240 \mathrm{ft}-1 \mathrm{~b}$ was recently obtained. Efforts are now underway to fabricate a specimen heating chamber and transfer apparatus which will permit testing of Charpy impact specimens at temperatures up to $1000^{\circ} \mathrm{C}$.

A helium leak detector has been obtained; and a test chamber is now being designed which will permit leak testing of full size WESF strontium capsules. The chamber and leak detector will be used in qualification testing of the WESF capsule. 


\section{DISTRIBUTION}

NO. OF

COPIES

OFFSITE

1

\begin{tabular}{l} 
ERDA Chicago Patent Attorney \\
\hline 9800 S. Cass Avenue \\
Argonne, IL 60439
\end{tabular}

A. A. Churm

1

ERDA Division of Biomedical and Environmental Research Washington, DC 20545

J. N. Maddox

2

ERDA Division of Production and Materials Management Washington, DC 20545

F. P. Baranowski

R. W. Ramsey, Jr.

11

1

2
ERDA Nuclear Research and Applications Division Washington, DC 20545
R. T. Carpenter
G. P. Dix
T. J. Dobry, Jr.
N. Goldenberg
A. P. Litman (3)
J. J. Lombardo
W. C. Remini
B. J. Rock
E. J. Wahlquist

ERDA Dak Ridge Operations Office

P. 0. BOX E

Oak Ridge, TN 37830

D. C. Davis, Jr.

ERDA Savannah River Operations Office

P. 0. Box A

Aiken, SC 29801

R. H. Bass

T. B. Hindman 
Department of the Army Headquarters, U.S. Army

Facilities Engineering Support Agency

Fort Belvoir, VA 22060

H. Musselman, Technical Director

E. I. duPont de Nemours and Company Aiken, SC 29ou.

R. K. Huntoon

Electronics and Applied Physics Division Building 347.3, AERE Harwel1 Oxfordshire 0X11 ORA Great Britain
E. H. Cooke-Yarborough

General Atomic Company

P. 0. Box 81601

San Diego, CA 92138

H. C. Carney

General Electric Company MSVD

P. 0. Box 8555

Philadelphia, PA 19101

P. E. Brown

General Electric Company, Vallecitos Laboratory P. 0. Box 846

Pleasanton, CA 94566

G. E. Robinson

Los Alamos Scientific Laboratory

P. 0. Box 1663

Los Alamos, NM 87544

S. E. Bronisz

R. A. Kent

R. N. Mulford

Monsanto Research Corporation

Mound Laboratory (ERDA)

Nuclear Operations

P. 0. Box 32

Miamisburg, $\mathrm{OH} 45342$

W. T. Cave

R. Dewitt 
Naval Nuclear Power Unit

P. 0. Box 96

Fort Belvoir, VA 22060

F. E. Rosel1

1

Naval Facilities Engineering Command Nuclear Power Division (FACO4N)

200 Stovall Street

Alexandria, VA 22332

G. E. Krauter

1

Navy Office of the Chief of Naval Operations Washington, DC 20390

Head, Reactor Branch

4

Hol ifield National Laboratory Oak Ridge, TN 37830

R. S. Crouse

J. R. DiStefano

E. Lamb

A. C. Schaffhauser

3

Teledyne Energy Systems

$110 \mathrm{~W}$. Timonium Road

Timonium, MD 21093

P. Dick

R. Hannah

P. Vogelberger

1

Westinghouse Astronuclear Laboratory P. 0. Box 10864

Pittsburgh, PA 15236

C. C. Silverstein

ONSITE

ERDA Richland Operations

W. A. Burns

W. C. Johnson

P. G. Holsted 
L. I. Brecke

H. H. Hopkins

R. E. Isaacson

L. M. Knights

C. W. Malody

J. D. Moore

H. P. Shaw

Battel le-Northwest

D. G. Atteridge

J. W. Bartlett

D. B. Cash

T. D. Chikalla

M. O. Cloninger

C. W. Dawson

T. F. Demmitt

R. L. Dillon

H. T. Fullam (3)

K. M. Harmon

A. J. Haverfield

J. H. Jarrett

R. S. Kemper

R. P. Marshall

R. W. McKee

R. D. Nelson

J. M. Nielsen

R. E. Nightingale

D. E. Olesen

L. D. Perrigo

A. M. Platt

W. E. Sande

J. L. Simmons

H. H. Van Tuyl

R. E. Westerman

Technical Information Files (3)

Technical Publications 